\title{
LIVING ARTIFICIAL HEART VALVE ALTERNATIVES: A REVIEW
}

\author{
Thomas C. Flanagan ${ }^{1,2}$ and Abhay Pandit ${ }^{2 *}$ \\ ${ }^{1}$ Department of Anatomy, and ${ }^{2}$ National Centre for Biomedical Engineering Science, National University of Ireland \\ Galway, Galway, Ireland
}

\begin{abstract}
Conventional replacement therapies for heart valve disease are associated with significant drawbacks. The field of tissue engineering has emerged as an exciting alternative in the search for improved heart valve replacement structures. One of the principles behind this concept is the transplantation of living elements, embedded in a suitable scaffold material, to the diseased site where the structure becomes integrated with patients' tissue to restore natural function. Significant progress has been made in the last ten years in the development of a living artificial heart valve alternative (LAHVA), with the identification of potential replacement sources for valve cells, scaffolds to maintain the cells in a three-dimensional environment, and signals to promote tissue development. This review addresses the need for a tissue-engineered alternative to current prostheses and provides a detailed account of normal heart valve structure - the blueprint for LAHVA fabrication. The research efforts to create a viable LAHVA, including recent developments, are discussed. Particular attention is focused on the choice of cell source for LAHVA construction, the use of biodegradable natural and synthetic polymeric scaffolds as extracellular matrix derivatives, and exogenous stimulation of tissue growth. The critical challenges involved in LAHVA development and possible future areas of investigation are also discussed.
\end{abstract}

Key Words: Heart valve, tissue engineering, cardiovascular system, extracellular matrix, heart valve prosthesis, interstitial cell, endocardial cell, biodegradable scaffold, bioreactor, growth factor.

\footnotetext{
*Address for correspondence:

Abhay Pandit

Department of Mechanical and Biomedical Engineering, National University of Ireland Galway

Nun's Island, Galway, Ireland
}

Telephone No: $+353(0) 91512395$

FAX No: +353 (0)91 563991

E-mail: abhay.pandit@nuigalway.ie

\section{Introduction}

Heart valve disease has a devastating impact worldwide; the American Heart Association reports an estimated 87,000 heart valve replacement procedures in 2000 (American Heart Association, 2002), while approximately 275,000 procedures are performed globally each year (Rabkin and Schoen, 2002). Cited as the cause of death in 19,737 cases during 2000 in the US alone, heart valve disease was a contributing factor in an estimated 42,300 further cases (American Heart Association, 2002). Heart valve disease occurs when one or more of the four heart valves can no longer perform their function adequately as gateways in the circulation, failing to maintain a competent unidirectional flow of blood through the heart. Two principal types of valve disease can develop which prevent the valves from opening or closing properly. The first type, valvar stenosis, is characterised by a marked narrowing of the valve opening. The second type, valvar insufficiency, occurs when the valve does not form a tight seal upon closure, resulting in regurgitation of blood. Both disease types burden the heart with an increased work rate to maintain stroke volume, leading to heart muscle dysfunction and eventually heart failure (Carabello and Crawford, 1997). Although the treatment of choice for many years has been surgical valve repair (Alvarez and Murday, 1995), complete valve replacement is warranted in the most advanced of cases.

\section{Current Treatment and Associated Limitations}

Exploration into heart valve replacement began in the 1950 s, with the first successful human valve implantation being performed in 1952 (Hufnagel et al., 1952). Subsequent decades saw the development of more than 80 designs of prosthetic heart valves (Vongpatanasin et al., 1996); these remain the most common treatment for advanced heart valve disease (Schoen and Levy, 1999). Prosthetic heart valves may be either mechanical, consisting entirely of synthetic components, or may be fashioned from biological tissue (bioprosthetic). $55 \%$ of implanted valves worldwide are mechanical, with the remaining $45 \%$ bioprosthetic (Butany et al., 2003a); while both types prolong life as well as enhancing its quality, they are associated with a number of major complications that limit their success (Schoen and Levy, 1994).

Advances in engineering and biomaterials have enabled the design of efficient mechanical heart valves (Korossis et al., 2000). The major advantage of mechanical heart valves is their durability and longevity (life span $>25$ years) - making them more suitable than bioprosthetic valves for 
paediatric patients. However, the body's natural response to foreign materials can often result in thrombosis, which can lead to mortality. For this reason, patients receiving mechanical heart valves are placed on long-term anticoagulation therapy. Other limitations with mechanical valves are their association with infective endocarditis, risk of failure or separation of valvar components which may become embolised (Vongpatanasin et al., 1996).

Bioprosthetic valves may be constructed from either animal-derived tissue (xenografts) or human-derived tissue (homografts) (Butany et al., 2003b). Xenografts are typically composed of either porcine aortic tissue or bovine pericardial tissue, and are normally mounted on a supporting frame. These valves are generally treated with a chemical cross-linking agent, such as glutaraldehyde, in order to increase their durability. Advantages of xenografts include an unlimited supply of donor tissue and superior hemodynamics to mechanical valves (Butany et al., 2003b). Additionally, recipients generally do not require anticoagulation treatment since the surface of bioprosthetic valves carries a lower thrombogenic risk than mechanical valves. However, progressive tissue deterioration afflicts biological replacements with a significantly short life-span (10-15 years) (Hammermeister et al., 1993), and consequently they are seldom used in younger patients in whom they are more susceptible to calcification (Curcio et al., 1981; al-Khaja et al., 1991).

Cryopreserved cadaveric homografts or healthy valves from heart transplant patients are also used as valve replacements, the natural biological form of the leaflets contributing to the enhanced functional performance of the graft. The tissue contains viable, living cells, making it more biocompatible than either mechanical or xenograft valves. Thromboembolic complications are also quite low (Mitchell et al., 1995). In spite of these advantages, however, the longterm function and durability of homografts is still inadequate (Angell et al., 1989). There is always a risk of damage to the valves through chronic rejection, with the foreign tissue evoking an immune response in the patient. Although there is little evidence of acute rejection, there are reports of rapid failure of homograft valves in infants (Rajani et al., 1998). A further drawback of homografts lies in their limited supply due to a shortage of donor tissue.

The underlying problem with all current methods of heart valve replacement is that the non-living material lacks an intrinsic repair system that can recondition the valve after structural injury. Optimal valve replacement tissue should be biocompatible whilst exhibiting growth and reparative capabilities (Nugent and Edelman, 2003). In recent years investigators have begun to focus their efforts on the development of living, functional replacements for tissue damaged through disease or injury (Langer and Vacanti, 1993). Current strategies in this arena of tissue engineering include transplantation of constructs containing specific cell types to the site of injury following an in vitro conditioning period (in vitro colonisation approach), or constructs which will recruit endogenous progenitor or differentiated cells from the surrounding tissue (in vivo colonisation approach). Either of these constructs, theoretically, could functionally integrate with the host tissue and encourage tissue regen- eration. A thorough knowledge of normal heart valve development and functional tissue composition is an essential prerequisite to establish the desired structural makeup of a tissue-engineered alternative (Rabkin and Schoen, 2002).

\section{Heart Valve Structure - The Blueprint for a Tissue- Engineered Replacement}

The four heart valves arise from embryonic mesenchymal outgrowths referred to as the endocardial cushions in a process termed valvuloseptal morphogenesis (Eisenberg and Markwald, 1995); two valves form in the atrioventicular (AV) canal (the tricuspid (trileaflet) and mitral (bileaflet) AV valves), with two valves forming in the ventricular outflow tract (aortic and pulmonary arterial valves - both trileaflet). It has been widely accepted that all heart valves are simple structures whose contribution to the unidirectional flow of blood was merely passive movement in response to pressure gradients across the valve (Cooper et al., 1966). This understanding of 'passive structures' led to the development of the 'passive' mechanical and bioprosthetic valve replacements. It is now becoming apparent, however, that the heart valves have a more complex structure specialised for the microenvironment in which they are placed (Yacoub et al., 1999). A living artificial heart valve alternative (LAHVA) will need to assume an identical structure if it is to replace the current modes of valve treatment; an in-depth knowledge of valvar components and their interaction will be critical to accomplish significant breakthroughs in the field.

\section{Principal heart valve cell types}

The principal cell types in the heart valve are the valvar interstitial cells (VICs) and valvar endocardial cells (VECs), with smooth muscle, cardiac muscle and nerve cells also present to varying degrees depending on the specific valve under consideration (Cooper et al., 1966; Fenoglio et al., 1972; Hibbs and Ellison, 1973).

Valvar interstitial cells. VICs, believed to be responsible for maintenance of valvar structure, are numerous, elongated cells with many long, slender processes extending throughout the valve matrix (Filip et al., 1986). They connect to each other to establish a three-dimensional network throughout the entire valve, and are intimately associated with the valve matrix. It has been suggested that there may be two morphologically and structurally distinct populations of VICs - one possessing contractile properties, characterised by prominent stress fibres, and one possessing secretory properties, characterised by prominent rough endoplasmic reticulum (rER) and Golgi apparatus (Filip et al., 1986; Lester et al., 1988; Zacks et al., 1991). Components characteristic of smooth muscle cells suggest VICs have functional capabilities other than fibroblast matrix secretion (Filip et al., 1986; Messier et al., 1994), and it is possible that in vivo some VICs are able to contract in order to maintain a limited intrinsic valvar force and withstand hemodynamic pressures (Mulholland and Gotlieb, 1997). Contractile function is further supported by the expression of both cardiac and skeletal contractile 
proteins in VICs, which include $\alpha$ - and $\beta$-myosin heavy chain and various troponin isoforms (Roy et al., 2000). Valve leaflet contraction has been demonstrated in response to a range of vasoactive agents, suggesting a coordinated contribution of biological stimuli to successful valve function (Chester et al., 2000; Chester et al., 2001; Misfeld et al., 2002). The main characteristics of VICs are summarised in Table 1.

VICs are also the essential components of the intrinsic repair system of the valve. The constant motion of the valve leaflets, and connective tissue deformations associated with that movement produce damage to which the VICs respond in order to maintain valvar integrity. This regenerative process appears to be vital to normal valvar function (Schneider and Deck, 1981; Henney et al., 1982), and the absence of VICs in current prosthetic heart valve models is a probable factor contributing to structural failure.

Although extensive data exists regarding the heterogeneity and reparative properties of the VIC population, their function is still quite vague. An important avenue of VIC research will be translation of the cross-talk between the cells and their surrounding matrix mediated through focal adhesion molecules. Focal adhesions are specialised cell-matrix attachment sites linking the cell cytoskeleton to the matrix proteins via integrins. They also act as signal transduction sites, transmitting mechanical information from the ECM, which can elicit a number of responses including, but not limited to, cell adhesion, migration, growth and differentiation (Sastry and Burridge, 2000; Weber et al., 2002). An understanding of the cell biology of VICs is vital in order to determine the mechanisms by which these cells interact with each other and their surrounding environment, in order that this function can be reproduced in a LAHVA.

Valvar endocardial cells. The other major valve cell type is the VEC, which forms a functional envelope around each of the four heart valves. Whilst there is significant data on the various functions of vascular endothelium (Bachetti and Morbidelli, 2000), the specific role of valve endocardium remains unclear and has not been widely studied. However, it seems reasonable that the VECs act to maintain a nonthrombogenic valve surface, similar to the vascular endothelium (Frater et al., 1992). Current valve replacements are devoid of a functional, protective endocardium. This may result in platelet and fibrin deposits on glutaraldehyde-fixed bioprosthetic valves, bacterial infection and tissue calcification (Frater et al., 1992; Lehner et al., 1997).

Another likely function of VECs is the regulation of the underlying VICs, similar to the regulation of vascular smooth muscle cells by the endothelium (Mulholland and Gotlieb, 1997). A complex interaction exists between endothelium and neighbouring cells, mediated in part by soluble factors secreted by endothelial cells (Guarda et al., 1993). A sensory role for VECs has also been proposed by Hill and FolanCurran (1993); these cells present a large surface area covered with microappendages on their luminal aspect thus increasing exposure to, and possible interaction with, metabolic substances in the circulating blood.

Endothelium often displays morphological and functional differences related to the stress generated by blood flow, and the same is true for VECs, with both elongated and polygonal cells being observed (Hurle et al., 1985). The changes in cell structure may be due to the effects of local hemodynamics on either the cytoskeletal components of the cell, or a secondary effect incurred by changes in the underlying extracellular matrix material. Ultrastructurally, VECs have been shown to possess cell junctions, plasmalemmal vesicles and rER (Table 2); although they express von Willebrand factor (vWf) both in vitro and in vivo, they lack Weibel-Palade bodies \{specific storage granules for von Willebrand factor\} (Lester et al., 1993), which are characteristic organelles of vascular endothelium. In situ, abutting VECs are linked together by tight junctions and gap junctions as well as overlapping marginal edges - the so-called marginal folds (Harasaki et al., 1975; Manduteanu et al., 1988).

Endothelial cells and endocardial cells preserve some of their main metabolic activities in vitro (Manduteanu et al., 1988), providing suitable cell markers for their identification. The cells express vWf in two-dimensional cell culture (Manduteanu et al., 1988) and demonstrate angiotensin converting enzyme (ACE) activity (Manduteanu et al., 1988; Bachetti and Morbidelli, 2000). The cells have also been shown to produce prostacyclin (Manduteanu et al., 1988) and have demonstrated endothelial nitric oxide synthase (eNOS) expression and activity (Smith et al., 1993; Siney and Lewis, 1993). These markers are useful in identifying ideal cell culture isolates in developing a LAHVA, but the immune-stimulating potential of VECs themselves may limit their use in tissue-engineered structures. Simon et al. (1993) report the expression of major histocompatability complex (MHC) antigens on cultured VECs, suggesting that an allogeneic valve may provoke immunological reactions in the recipient contributing to rapid valve degeneration. VECs also express the adhesion molecules ICAM-1 and ELAM-1, which are important for the binding of mononuclear cells during an immune response (Simon et al., 1993). Batten et al. (2001) have demonstrated a similar range of $\mathrm{MHC}$ and adhesion/co-stimulatory molecules in VECs and VICs, but only VECs were immunogenic. Although patient-derived autologous VECs present an ideal cell source to construct a LAHVA it may not be clinically feasible to harvest an adequate valve tissue sample. Finding a suitable endocardial replacement cell source is just one of the many hurdles that must be overcome in realising the goal of a LAHVA.

\section{Heart valve extracellular matrix}

Histologically, the heart valve leaflet consists of a valve interstitial matrix enveloped by a continuous monolayer of VECs. The principal components of the valve extracellular matrix (ECM) are the fibrous macromolecules collagen and elastin, proteoglycans and glycoproteins, each component conferring unique physical and mechanical properties (Kunzelman et al., 1993). Collagen accounts for $\sim 60 \%$ dry weight of the valve, elastin for $\sim 10 \%$ and proteoglycans for $\sim 20 \%$ (Kunzelman et al., 1993). The collagen component, which provides most of the mechanical strength of the valve, is predominantly type I and III (74\% and 24\% respectively) with $\sim 2 \%$ of type $\mathrm{V}$ collagen (Cole et al., 1984). The collagen 
Table 1 Characteristics of valvar interstitial cells (VICs)

\section{Anatomical or Physiological Feature: \\ Cytoskeleton}

Contractility

Cell communication

Matrix secretion

Innervation

Mitogenic factors

F i b r o b 1 a s t characteristics

\section{Evidenced by:}

$\alpha$-smooth muscle actin ( $\alpha$-SMA) staining Vimentin staining

Desmin staining

Smooth muscle cell myosin staining

Troponin T, I, C staining

$\alpha$-myosin heavy chain $(\alpha-\mathrm{MHC})$ staining

$\beta$-myosin heavy chain ( $\beta$-MHC) staining

Cardiac myosin light chain-2 (MLC2) staining

$\alpha$-tubulin staining

$\beta$-tubulin staining

Positive response to epinephrine, angiotensin II Positive response to bradykinin, carbachol, potassium chloride, endothelin I

Functional gap junctions (tested by microinjection of carboxyfluorescein)

Prolyl-4-hydroxylase / Collagen type I staining Fibronectin staining

Chondroitin sulphate staining

Laminin staining

Close apposition to motor nerve terminals

Proximity to nerves displaying:

Neuropeptide Y activity

Tyrosine hydroxylase activity

Acetylcholineesterase activity

Vasoactive intestinal polypeptide (VIP) activity

Substance-P activity

Calcitonin gene-related peptide (CGRP) activity

Platelet-derived growth factor (PDGF) - mitogenic effect

Basic fibroblast growth factor (bFGF) - mitogenic effect

Serotonin (5-HT) - mitogenic effect

Incomplete basal lamina

Long, thin cytoplasmic processes

Intimate association with matrix

Well-developed rough endoplasmic reticulum and

Golgi apparatus

Rich in microfilaments

Adherens junction formation

\section{Reference:}

Filip et al., 1986; Taylor et al., 2000

Lester et al., 1988; Messier et al., 1994;

Taylor et al., 2000

Messier et al., 1994; Taylor et al., 2000

Lester et al., 1988; Taylor et al., 2000

Roy et al., 2000

Roy et al., 2000

Roy et al., 2000

Roy et al., 2000

Messier et al., 1994

Taylor et al., 2000

Filip et al., 1986, Messier et al., 1994

Messier et al., 1994

Filip et al., 1986

Messier et al., 1994; Taylor et al., 2000

Messier et al., 1994; Flanagan et al., 2003

Messier et al., 1994; Flanagan et al., 2003

Flanagan et al., 2003

Filip et al., 1986

Marron et al., 1996; Ahmed et al., 1997

Marron et al., 1996; Ahmed et al., 1997

Marron et al., 1996; Ahmed et al., 1997

Marron et al., 1996

Marron et al., 1996; Ahmed et al., 1997

Ahmed et al., 1997

Johnson et al., 1987

Messier et al., 1994

Hafizi et al., 2000

Filip et al., 1986 
Table 2 Characteristics of valvar endocardial cells (VECs)

\author{
Anatomical or Physiological \\ Feature: \\ Morphology
}

Cytoskeleton

Metabolic function

Cell communication

Ultrastructural features
Evidenced by:

Cobblestone shape (2-D culture)

Regional differences in situ (cobblestone/ elongated)

Surface microappendages

Marginal folds

Actin staining

Vimentin staining

Von Willebrand factor (vWf) production Angiotensin converting enzyme (ACE) activity

Prostacyclin biosynthesis

Endothelial nitric oxide synthase (eNOS) production

Tight junction formation Functional gap junctions (tested by microinjection of carboxyfluorescein)

Lack of Weibel-Palade bodies

Plasmalemmal vesicles / caveolae

Prominent rough endoplasmic reticulum

and Golgi apparatus

\section{Reference:}

Manduteanu et al., 1988

Hurle et al., 1985

Hill and Folan-Curran, 1993

Harasaki et al., 1975

Garcia-Martinez and Hurle, 1986

Garcia-Martinez and Hurle, 1986

Manduteanu et al., 1988

Manduteanu et al., 1988

Manduteanu et al., 1988

Smith et al., 1993; Siney and Lewis, 1993

Lupu and Simionescu, 1985

Lupu and Simionescu, 1985

Lester et al., 1993

Filip, 1984; Rajamannan et al., 2002

Manduteanu et al., 1988

Table 3 Principal ECM components of the heart valve layers

$\begin{array}{ll}\begin{array}{l}\text { Valve layer } \\ \text { (Atrialis) }\end{array} & \begin{array}{l}\text { Main ECM co } \\ \text { (Elastin) }\end{array} \\ \text { Fibrosa } & \text { Collagen } \\ \text { Spongiosa } & \text { Proteoglycans }\end{array}$

Ventricularis Elastin

\section{Function}

(Recoil of AV valves during closure)

Tensile strength

Formation of hydrated lattice

Resistance against compressive forces

Retention of corrugated collagen structure

in aortic valve

Recoil of arterial valves during closure fibre bundles appear to be surrounded by an elastin matrix, which provides interconnections between the collagen fibres (Scott and Vesely, 1995). The glycosaminoglycan (GAG) side-chains of proteoglycan molecules tend to form a gel-like ground substance in which other matrix molecules interact to form permanent cross-links and on which other components are deposited. Human heart valve GAGs consist mainly of hyaluronic acid (HA), followed by dermatan sulphate (DS), chondroitin-4-sulphate (C-4S) and chondroitin-6-sulphate (C-6S), with minimal heparan sulphate (HS), in decreasing concentration (Murata, 1981).

The deposition and subsequent remodelling of ECM components help to determine many of the mechanical characteristics of the heart valve; however, the appropriate bio- logical, chemical and physical cues are not yet completely understood. Both tissue remodelling and renewal observed in the connective tissue of structures such as heart valves are mediated primarily by the matrix metalloproteinases (MMPs) and their tissue inhibitors (TIMPs). These molecules also participate in a broader spectrum of physiological and pathological processes (Nelson et al., 2000; McCawley and Matrisian, 2001; Galis and Khatri, 2002). Several MMPs, including interstitial collagenases (MMP1, MMP-13) and gelatinases (MMP-2, MMP-9) and their TIMPs (TIMP-1, TIMP-2, TIMP-3) have been localised in all four heart valves (Dreger et al., 2002). Over-expression of MMPs has also been demonstrated in pathological heart valve conditions (Rabkin et al., 2001). Further stud- 


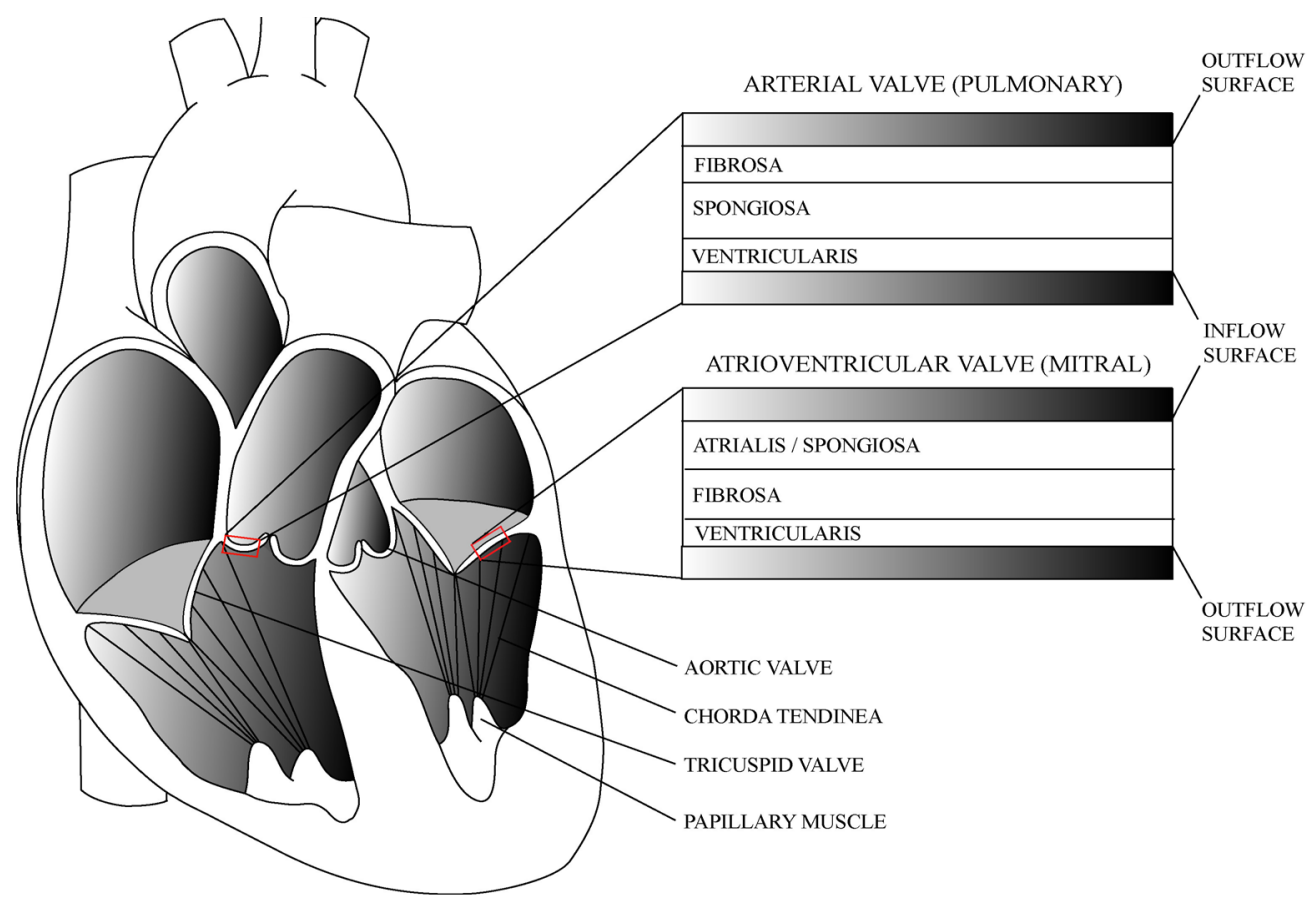

Figure 1 Schematic arrangement of the connective tissue layers through the mid-zone of the heart valve leaflets

ies are necessary to elucidate their mechanism of action and functional implications in valve matrix turnover and tissue morphogenesis.

Each of the three major structural valve components (collagen, elastin and proteoglycans) constitutes a significant proportion of each of the three morphologically distinct and functionally significant layers of the valve leaflet matrix (Table 3). These layers are termed the fibrosa, spongiosa, and ventricularis (Gross and Kugel, 1931), although the arrangement of these layers differs in the AV and arterial valves (Figure 1). The AV valves also possess an atrialis layer, but the atrialis and spongiosa layers will generally be considered together as the spongiosa layer for the purpose of this review.

Fibrosa. The fibrosa layer forms the load-bearing fibrous backbone of the valve leaflet, consisting of sheets of collagen bundles (Kunzelman et al., 1993). These bundles preferentially run in the transverse direction of the aortic valve leaflets and are arranged in a corrugated manner to allow expansion during valve closure (Missirlis and Armeniades, 1977). The fibrosa of the AV valves is continuous with the collagen core of the chordae tendineae (Figure 1) - a network of cord-like support structures anchored to the cardiac papillary muscles (Fenoglio et al., 1972). The chordae make up an important component of the AV valve complex, as they prevent the leaflets from ballooning into the atria during ventricular contraction. The fibrosa layer of the heart valves generally lies towards the outflow surface, and helps maintains proper function in the arterial valves as they are unsupported by chordae tendineae (Christov et al., 1999).

Spongiosa. The spongiosa layer consists of loosely organised connective tissue in a semi-fluid ground substance (Walmsley, 1978). The dominant matrix components of this layer are proteoglycans, with randomly oriented collagen interspersed with multiple fine layers of elastic tissue. GAG side-chains of proteoglycan molecules are highly negatively charged which results in a significant water-binding capacity and thus the formation of a porous gel matrix. Important mechanical functions of the proteoglycans include this matrix hydration, and the ability to resist compressive forces (Culav et al., 1999). The spongiosa layer of the heart valve may absorb stresses generated during valve closure (Kunzelman et al., 1993) and may sustain flexibility despite continuous valve motion (Murata, 1981). This layer may also enable shearing between the fibrosa and ventricularis layers of the aortic valve during loading and unloading.

Ventricularis. The ventricularis layer is much thinner than the other two layers, and is abundant in elastic fibres (Kunzelman et al., 1993). Elastic fibres allow tissues to withstand repeated deformation and reformation (Culav et al., 1999). Elastin is believed to be responsible for maintaining the aortic valve collagen fibre architecture in its neutral corrugated state (Scott and Vesely, 1995). It is also evident that the side of the valve which faces against the direction of blood flow (ventricularis in arterial valves, spongiosa in AV valves) contains a higher proportion of elastin than the opposite layer, and its flexibility allows the valve leaflets to recoil during valve closure (Christov et al., 1999).

In order to meet the extraordinary demands placed upon it, the valve possesses incredible strength, durability and flexibility due to its composite laminated structure. It will be crucial to recreate this layered structure in a LAHVA to maintain proper functionality amidst the turbulent conditions of the cardiac cycle. Any analysis of normal valve function must take into account the cellular organisation of the valve as well as the reciprocal interactions between the cells and their surrounding matrix. Knowledge gained from such 
studies is central to the design and development of a living replacement valve employing a tissue-engineered approach.

\section{Tissue Engineering Approach to Heart Valve Replacement}

Tissue engineering approaches emerged during the last 15 years in response to limitations associated with tissue and organ transplantation, with the scarcity of available donor tissue being perhaps the most significant limiting factor (Fuchs et al., 2001). The primary goal of tissue engineering is the 'restoration of function through the delivery of living elements which become integrated into the patient' (Vacanti and Langer, 1999). Tissue engineering approaches to the construction of a heart valve, or any tissue or organ, typically rely on three essential components (Figure 2): cells, which will ultimately form the new tissue; scaffolds, designed to maintain the cells in a three-dimensional environment at the implantation site, and signals that guide the gene expression and ECM production of the cells during tissue development.

\section{Cells}

Establishing a reliable cell source is a key to effective tissue regeneration (Langer and Vacanti, 1999). A variety of cell sources is applicable to tissue-engineered structures, each with associated advantages and disadvantages (Heath, 2000). One possibility is autogeneic cells, harvested from patients themselves, which would not elicit an immune reaction following re-implantation. However, in diseased states or with geriatric patients, autogeneic cells may not be an appropriate transplantation source (Heath, 2000). They would also be unavailable 'off-the-shelf' for immediate use clinically (Nerem and Seliktar, 2001).

Recent developments in stem cell research have had a significant impact on the progress of tissue engineering (Chapekar, 2000). This research has focussed particularly on multipotent (capable of forming a number of cell types) adult stem cells and totipotent (capable of forming all cell types) embryonic stem cells. However, a clearer understanding of the factors involved in their differentiation, as well as preservation of gene expression and phenotypic function in vivo is critical to maintain normal structure and function in a LAHVA.

The remaining possibilities for a LAHVA cell source include xenogeneic or allogeneic cells, although xenogeneic cells carry a risk of transferring animal viruses to humans (Nerem and Seliktar, 2001). There may be a possibility, however, to alter allogeneic cells genetically to reduce antigenicity or prevent host rejection (Heath, 2000). Regardless of cell source, the cells composing a tissue-engineered structure must express the appropriate genes and maintain the appropriate phenotype in order to preserve the specific function of the tissue (Kim and Mooney, 1998).

\section{Scaffolds}

Exogenous ECM scaffolds are designed to immobilise the appropriate cell populations at the implantation site of a tissue-engineered structure, and also to provide mechanical support until newly-formed tissue has been laid down,

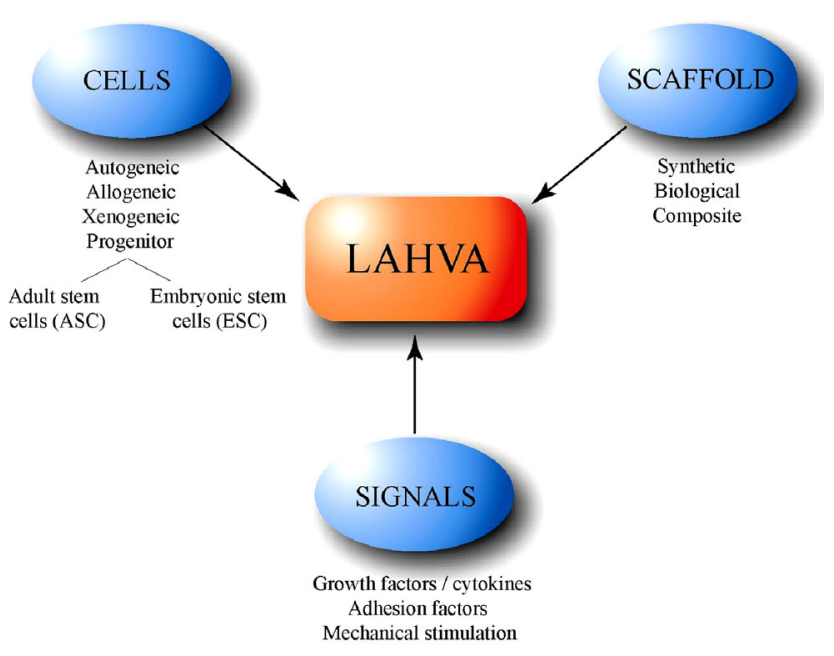

Figure 2 The principal building blocks for LAHVA fabrication

organised and become structurally stable (Putnam and Mooney, 1996). The traditional concept of tissue engineering involves the use of three-dimensional polymeric scaffolds as cell transplant devices. Once the cells are seeded on the scaffolds in vitro, the resulting three-dimensional construct can be implanted in vivo at the site of injury or disease. Implanted cells can then use the body's natural structural cues to promote organisation, growth and development of the replacement 'tissue'. The polymeric scaffolds are designed to degrade or hydrolyse in vivo as the implanted cells produce and organise their own extracellular matrix network, such that eventually only newly synthesised, functionally integrated tissue remains at the transplantation site. The two principal choices of scaffold currently under investigation are synthetic polymeric scaffolds or biological polymeric scaffolds.

\section{Signals}

Successful tissue regeneration may not always be achieved 'simply' by combining cells and scaffolds. The gene expression of cells and tissue formation can be regulated or promoted by the addition of growth factors, cytokines or hormones. A drug delivery feedback system can exploit this method of biochemical signalling, by controlling growth factor release at the site of tissue regeneration (Pandit et al., 2000; Tabata, 2000).

Cell adhesion molecules also impart a level of signalling that controls the regulation of gene expression and cellular organisation. Bioactivity of a synthetic polymer scaffold can be modified with covalently-attached adhesion peptide sequences, such as arginine-glycine-aspartic acid (RGD) or tyrosine-isoleucine-glycine-serine-arginine (YIGSR) (Hubbell, 1995). Such sequences are present on a number of ECM molecules, forming a physical link between the ECM and the cells via integrin cell surface receptors (Van der Flier and Sonnenberg, 2001). Incorporated sequences function to improve cell adhesion, spreading and higher functions, whilst also enabling integrin triggering of a number of cell signalling pathways critical to tissue development (Kim and Mooney, 1998). 
In vitro methods of mechanical stimulation or physical signalling have also been shown to improve cell and tissue growth. This has led to the design and development of bioreactor systems for the in vitro pre-conditioning of tissue-engineered structures (Barron et al., 2003); tissue formation thus takes place in an environment closely mimicking that of the transplant site.

\section{Current progress towards a LAHVA}

The design of LAHVAs incorporating cells, scaffolds and signals presents a unique challenge to researchers in the field. The optimum design will possess the following characteristics: an anatomical structure comparable to native valve; physiological function; biomechanical adaptability; reparative ability and growth potential. The valves must be able to open and close synchronously at a frequency of approximately $1 \mathrm{~Hz}$, resulting in bending deformations, and be exposed to the turbulent hemodynamics experienced within the heart (Mann and West, 2001).

Significant progress has been made to date in the tissue engineering of heart valve structures, with researchers concentrating their efforts on the ideal source of cell populations, the use of cell-seeded scaffolds and the promotion of tissue growth using various signals, in particular in vitro mechanical stimulation. The results of selected studies are summarised in Table 4 (to be found in supplemental file 'v006a04s.pdf').

Populations investigated as cell sources for a LAHVA

The concept of a LAHVA was first presented by Shinoka et al. (1995), who constructed valve leaflets using both allogeneic and autogeneic cells seeded on a biodegradable polymeric scaffold. A mixed population of smooth muscle cells and fibroblasts representing VICs was isolated from ovine femoral artery and subsequently seeded into scaffolds composed of polyglactin (PGLA) and polyglycolic acid (PGA). The constructs were then seeded with a monolayer of femoral artery endothelial cells representing VECs. The single leaflet structures were transplanted in the low-pressure pulmonary position in ovine models. The autogeneic structures performed better than allogeneic, the latter evoking inflammatory responses and infectious complications in the animal hosts. The study did however demonstrate the feasibility of LAHVA leaflet construction.

Subsequent studies also utilised ovine femoral arteryderived cells to fabricate valve leaflet constructs (Breuer et al., 1996; Shinoka et al., 1996). However, the use of the femoral artery is not ideal as an autogeneic cell source, due to the added complications of limb ischaemia from disruption of the lower limb arterial blood supply. To address this problem, Shinoka et al. (1997) designed a study compar- ing dermal fibroblasts to arterial myofibroblasts* as cells of origin for a LAHVA. Leaflets derived from dermal fibroblast were much thicker, more contracted and less organised than those derived from arterial myofibroblasts. The authors suggest that cells of mesodermal origin (such as arterial myofibroblasts) may provide more specialised phenotypic properties than ectodermally-derived skin fibroblasts, making mesodermal cell populations more suitable for the construction of a LAHVA.

Schnell and co-workers (2001) evaluated myofibroblasts derived from human saphenous vein as an alternative cell source for the tissue engineering of cardiovascular structures. The choice of peripheral veins represented a more clinically realistic cell source than the arterial structures previously used, and can be harvested with minimally invasive surgery. The myofibroblasts were cultured on polyurethane scaffolds for 6 weeks, following which they were shown to be viable and confluent. Collagen production was increased in saphenous 'neo-tissue' compared to that constructed using human aortic myofibroblasts, while mechanical testing also demonstrated superior stability in the saphenous structures. However, as with most previous studies using arterial cells, the production of other important structural and regulatory molecules remains to be elucidated.

Carotid artery-derived myofibroblasts have also been harvested for the construction of a LAHVA (Stock et al., 2000; Sodian et al., 2000a; Hoerstrup 2000a); however, as with all other previous cell types isolated for the same purpose, this requires the sacrifice of an intact tissue structure and requires invasive surgery. In the search for an alternative cell source, one group demonstrated the possibility of using autogeneic umbilical cord cells (Kadner et al., 2002a). The isolated cells represent a mixed population from umbilical cord artery, vein and the surrounding Wharton's jelly. Absence of endothelial cells was confirmed in vitro; cells demonstrated features of myofibroblast-like differentiation, such as expression of alpha smooth muscle actin, vimentin, and deposition of collagen types I and III. The cells were shown to attach well to biodegradable scaffolds, and formed a layered tissue-like structure comparable to scaffolds seeded with vascular cells (Hoerstrup et $a l ., 2000 a)$. Deposition of collagen types I and III was demonstrated, although there were low levels of GAGs produced, and no report of elastin production. There are also a number of other limitations to this study; although Wharton's jelly myofibroblasts, the umbilical cord artery or veinderived cells on their own may represent a promising cell source, the authors present a study with a 'mixed' population of cells from all three structures. There is also limited immunohistochemical characterisation of this 'mixed' population, and further characterisation studies of pure cell

*Many papers have misleadingly referred to cells isolated from veins and arteries as 'myofibroblasts', with minimal characterisation. It has been proposed that most examples of cells cited in the literature as being myofibroblasts and seen in normal, non-traumatised, non-pathological tissues may be pericytic or smooth-muscle in nature (Eyden et al., 1994). Indeed, the vascular-derived cells are more likely to be smooth muscle cells, which are generally either synthetic or contractile. This again highlights the importance of extensive cell characterisation, and a standardisation of the cell terminology is of paramount necessity. Solely for the purpose of this review, the authors will cite the terminology used by the original authors. 
lines from each source will be necessary to significantly evolve this approach.

Mesenchymal stem cells (MSCs) are present in adult bone marrow, and have been demonstrated to develop into a variety of connective tissues, including bone, cartilage, muscle and fat (Pittenger et al., 1999; Caplan and Bruder, 2001). With this in mind, Kadner and colleagues investigated the feasibility of creating functional LAHVAs using human bone marrow stromal cells (Kadner et al., 2002b; Hoerstrup et al., 2002). Cell populations are easily harvested from a patient using simple bone marrow puncture, avoiding the sacrifice of an intact blood vessel. Isolated cells were partially characterised using a number of myofibroblast markers, and, like umbilical cord cells, were shown to express alpha smooth muscle actin and vimentin, and produce collagen types I and III. Biodegradable polymeric scaffolds cultured with MSCs in vitro demonstrated an organised internal structure and mature tissue development. Despite the encouraging results, it is essential that the bone marrow stromal cells differentiate into the appropriate cell type in the scaffold, and that they remain differentiated in vivo, in order to ensure long-term function and durability of the implanted LAHVA (Perry et al., 2003). Further investigation into the mechanisms and signals that direct bone marrow stromal cell differentiation are warranted before introduction in the clinical setting.

Although some promising results have been obtained using the aforementioned cell types, the ideal cell replacements for a LAHVA would be VICs and VECs themselves. A recent report discusses the use of heart valve leaflet biopsy samples from an ovine model as a tissue source for the cultivation of VICs for use in LAHVA fabrication (Maish et al., 2003). In most cases, the biopsy procedure did not appear to compromise leaflet function, with the majority of animals showing intact valves with normal leaflet anatomy post-mortem (9 out of 13). Long-term followup studies are required (the maximum investigation period was 17 weeks); however, it is unlikely that enough cells could be isolated and cultured from a small biopsy to be of clinical use. It is also known that cell numbers decrease with age, making this technique even less feasible in the older patient. The risks involved in valve biopsy may also be too high to justify human trials.

The search for an ideal replacement for both cell types is ongoing, with other potential sources of interest including circulating endothelial and smooth muscle progenitor cells (Rafii, 2000; Simper et al., 2002). However, all current techniques assume that transplanted cell populations achieve the same distribution and differentiation pattern of cells in the native valve (Bertipaglia et al., 2003). In previous studies, there is limited data regarding the phenotypic profile of these cells once they are implanted into the scaffolds, and future studies will need to provide extensive characterisation profiles of tissues both prior to implantation and during long-term follow-up studies. It is highly probable that both embryonic and adult stem cells will become valuable resources for construction of a number of tissues ex vivo, including heart valves.

\section{Scaffolds investigated as ECM templates for a LAHVA}

Synthetic biodegradable polymeric scaffolds. The work by Mayer et al. at the Children's Hospital, Boston in the mid-to-late 1990s involved the application of the biodegradable polymers PGA and polylactic acid (PLA), and composites of these polymers (PGLA), in the development of a LAHVA (Shinoka et al., 1995; Breuer et al., 1996; Shinoka et al., 1996; Zund et al., 1997). The scaffolds were composed of a PGLA woven mesh sandwiched between two non-woven PGA mesh sheets. The constructs were first seeded with arterial myofibroblasts, secondly with arterial endothelial cells, and were subsequently transplanted as a single leaflet into the pulmonary position in an ovine model. Seeded cells were shown to persist in the structure after 6 weeks in vivo (Shinoka et al., 1996). Histological examination of the leaflet structures post-mortem revealed a cellular architecture and tissue structure similar to that of native valve, although inflammatory responses and complications due to infection in the animal study were evident (Shinoka et al., 1995). The scaffold also persisted for at least 6 weeks after implantation. There was evidence for elastin and collagen production in the leaflets, which had mechanical properties similar to native leaflets (Shinoka et al., 1996). The success of these studies was limited, however, as the PGA-PLA polymers proved to be too immalleable to function as flexible valve leaflet structures. Kim and associates (2001) attempted to conduct a study to compare the biological responses of autogeneic cell-seeded PGA-PLA scaffolds and an acellular PGA-PLA scaffold by implanting both structures in the pulmonary position of the same animal. However, they failed to achieve long-term survival in animals with double valve leaflet replacement. They attributed this to heart failure caused by high-grade valvar insufficiency.

The high initial stiffness and thickness using PGA-PLA scaffolds warranted the investigation of new polymers. Stock and colleagues (2000) evaluated the use of polyhydroxyoctanoate (PHO) as part of a composite scaffold for the creation of a LAHVA. The fabricated valvedconduit consisted of four different biomaterials: the conduit wall was composed of a layer of non-porous PHO film ( $240 \mu \mathrm{m}$ thick) sandwiched between two layers of nonwoven PGA felt (each $1 \mathrm{~mm}$ thick). The leaflets consisted of a monolayer of porous PHO $(120 \mu \mathrm{m}$ thick), and were sutured to the wall of the conduit using polydioxanone sutures. Microscopical examination after explantation revealed a uniformly organised, fibrous tissue with significant amounts of stainable collagen and proteoglycans, but without stainable elastin. However, the PHO scaffold was still evident in the conduit and leaflets after 24 weeks, suggesting a much longer degradation profile than PGA or PLA, and this extended period could have the potential to augment host-tissue reactions. The study was also limited to implantations in the low-pressure pulmonary position.

An additional study involved moulding a porous $\mathrm{PHO}$ scaffold into a trileaflet valved-conduit through a thermal processing technique, with subsequent seeding of ovine carotid artery myofibroblasts and jugular vein endothelial cells (Sodian et al., 2000b). The constructs, devoid of 
polydioxanone sutures, were implanted into the pulmonary position in ovine models, and were harvested after 1 - 17 weeks. All valve constructs opened and closed synchronously, and showed an increase in inner diameter and length. This could not conclusively be attributed to actual tissue growth, and may simply have been dilatation of the construct. Scanning electron microscopical studies demonstrated a smooth flow surface on the leaflets, although they did not demonstrate a confluent endothelium using histological techniques. This limitation could affect the longterm durability of the structures. There was evidence for collagen and GAG deposition, but the constructs were devoid of elastin. All valve constructs demonstrated mild stenosis and regurgitation, and there was evidence for inflammatory reaction. The scaffold material remained after 17 weeks in vivo, and further long-term studies are required to monitor complete scaffold degradation.

PHO scaffold was evaluated as an alternative to PGAPLA, but demonstrated prolonged degradation time in vivo, and was not sufficiently replaced by neotissue after 24 weeks (Stock et al., 2000). Hoerstrup and colleagues (2000a) developed a novel composite scaffold material consisting of PGA coated with a thin layer of poly-4hydroxybutyrate (P4HB) - a flexible, thermoplastic polymer with a more rapid degradation time than PHO (Martin and Williams, 2003). Trileaflet heart valve scaffolds were fabricated from the composite material using a heat-application welding technique. Myofibroblasts and endothelial cells from ovine carotid artery were seeded onto the scaffolds, which were then cultured in a bioreactor for 14 days (Hoerstrup et al., 2000a). The conditioned constructs were subsequently implanted into the same lambs from which the cells were harvested, where they remained for up to 20 weeks. After in vitro conditioning, constructs showed increased ECM synthesis, more organised internal structure and improved mechanical properties over static controls. The leaflets demonstrated a layered architecture after 16 and 20 weeks, with a loose, spongy layer containing elastin and GAGs on the inflow (ventricular) surface, and a more fibrous layer containing primarily collagen on the outflow (arterial) surface. However, the valves showed moderate regurgitation at 20 weeks, and only partial endothelial cell coverage of the leaflet surface.

Decellularised tissue scaffolds. Decellularisation approaches may reduce the immune response of the host to bioprosthetic valves and generate natural materials for use in tissue engineering applications (Schmidt and Baier, 2000). The acellular biological matrix that remains offers a physiological template, which holds the potential for endothelialisation by surrounding host VECs and repopulation by local VICs. Theoretically, VECs will form a non-thrombogenic surface layer, while VICs will induce matrix turnover in the valve. This process would ultimately transform the allogeneic or xenogeneic acellular matrix into a primarily autogeneic, living valve tissue, with concurrent reduction in immune response. There are various methodologies available for decellularisation of heart valve tissue, including detergent treatments, enzymatic digestion, hypo-/hypertonic immersion and sonication.

Wilson and colleagues (1995) developed a cell extraction process for decellularising heart valves using both de- tergent (Triton X-100) and enzymes (DNAse, RNAse). The process removes cell membranes, nucleic acids, lipids, cytoplasmic structures, and soluble matrix molecules, while retaining the collagen and elastin ECM suitable for recellularisation (Zeltinger et al., 2001). After one month of follow-up using decellularised allografts in a canine model (Wilson et al., 1995), explant histology demonstrated no inflammatory process, partial VIC infiltration at the valvar base, and partial endothelialisation. Long-term calcification studies were not performed.

Bader and colleagues (1998), employing the decellularisation strategy of Wilson et al. (1995), demonstrated reseeding of acellularised porcine aortic valves with human endothelial cells, resulting in a confluent surface monolayer of viable cells. Endothelialisation of LAHVAs is an important preconditioning factor, in order to reduce thrombogenic risk. These authors demonstrated a largely acellular structure across the thickness of the leaflet. The collagen network appeared wavelike, as in normal valve tissue; however, there were large interfibrillar spaces that may have affected the mechanical properties of the tissue. It was also impossible to exclude the presence of cellular remnants in the tissue structure. This may be an important factor, as cellular remnants have been associated with calcification in microscopic investigations (Valente et al. 1985, Schoen et al. 1985). The extraction of cellular remnants should also minimise the immune response (Schmidt and Baier, 2000).

Bader and colleagues extended their studies to the in vivo application of an acellular matrix valve scaffold conditioned by tissue engineering in vitro using autogeneic cells (Steinhoff et al., 2000). Carotid artery myofibroblasts and endothelial cells were added sequentially to acellularised pulmonary valve conduits and were implanted into ovine models. The valve leaflets were completely endothelialised at 4 weeks, with the endothelium remaining confluent at 12 weeks after implantation, and had been infiltrated by a dense population of myofibroblasts. However, there was evidence for subvalvular calcification and inflammatory reaction. There was also an increased thickening of the valve leaflets; long-term studies were not undertaken.

The decellularisation approach is the basis for the commercially available SynerGraft ${ }^{\mathrm{TM}}$ valve manufactured by CryoLife Inc., USA (O'Brien et al., 1999). The SynerGraft ${ }^{\mathrm{TM}}$ decellularisation process involves cell lysis in sterile water, enzymatic digestion of nucleic acids (RNase and DNase enzymes in an unspecified buffer), followed by a multi-day isotonic washout period. The process was developed to replace the use of glutaraldehyde cross-linking to limit xenograft antigenicity. Histological examination after 150 day implantation in porcine models revealed intact leaflets with ingrowth of host myofibroblasts and no evidence for calcification. However, early failure of the valve has been reported in human trials (Simon et al., 2003). The SynerGraft ${ }^{\mathrm{TM}}$ matrix elicited a strong inflammatory response which was non-specific early on and was followed by a lymphocyte response. Structural failure or rapid degeneration of the valves occurred within one year. There was no host cell repopulation of the valve matrix, and evidence for calcific deposits and cellular remnants pre-implantation may indicate manufacturing problems. 
The ideal heart valve decellularising agent remains unknown. In a recent effort to determine the most efficient decellularising agent from a panel of candidates (Triton X100, sodium dodecyl sulphate (SDS), sodium deoxycholate, MEGA 10, TnBP, CHAPS and Tween 20), Booth and colleagues (2002) demonstrated that only SDS (0.03 - 1\%) or sodium deoxycholate $(0.5-2 \%)$ resulted in total decellularisation after 24 hours. However, the possible toxicity of decellularisation reagents remains a factor for investigation; more detailed characterisation studies of the matrix scaffold are crucial to determine appropriate matrix composition and complete elimination of cellular remnants. Biomechanical properties of decellularised valve tissue matrices also need to be analysed.

Natural biodegradable polymeric scaffolds. Anumber of naturally occurring biodegradable polymers have been investigated as potential LAHVA matrix structures, as they offer a more native environment than synthetic structures to the cells. Acellular small intestinal submucosal (SIS) matrix has been isolated to construct tissue substitutes (Badylak et al., 1989; Badylak et al., 1998). Matheny and colleagues (2000) have applied porcine SIS matrix as a resorbable scaffold for pulmonary valve leaflet replacement in porcine models. Analysis of explanted constructs revealed resorption of the submucosal matrix, progressive replacement with fibrous connective tissue and vascularisation similar to host leaflets. This approach appeared to yield complete resorption of the implanted scaffold in comparison to decellularised valve matrix applications.

The use of fibrin gel as a natural, autogeneic scaffold in heart valve tissue engineering has been demonstrated by Ye and associates (2000a), and has been the subject of investigation for the development of cardiovascular 'tissue equivalents' by Tranquillo and colleagues (Grassl et al., 2002; Neidert et al., 2002). Fibrin gel is a biodegradable polymer which can be produced from the patient's own blood. In the study by Ye and colleagues (2000a), cell-fibrin gel structures were constructed using human aortic myofibroblasts suspended in a solution of fibrinogen, thrombin and calcium chloride $\left(\mathrm{CaCl}_{2}\right)$ which was allowed to polymerise at $37^{\circ} \mathrm{C}$. The growth media was supplemented with L-ascorbic acid 2-phosphate - a potent promoter of collagen synthesis (Grinnell et al., 1989), and varying concentrations of aprotinin, a protease inhibitor, to adjust and control the rate of degradation. Microscopical studies demonstrated homogenous cell distribution and collagen synthesis; degradation was controlled by altering the aprotinin concentration. A moulding technique has also been developed for the application of this compound to trileaflet heart valve fabrication (Jockenhoevel et al., 2001a). An adjustable mould consisting of 'aortic' and 'ventricular' stamps was constructed from aluminium, and used to cast a trileaflet fibrin gel structure seeded with myofibroblasts within 1 hour. The tissue could withstand suturing, although its mechanical integrity was insufficient for direct implantation. Shrinkage of the gel structure also presents a complication. However, the fibrin gel model has a number of advantages: the scaffold itself can be produced directly from a sample of patient's blood eliminating the risk of rejection; the rate of degradation can be controlled and a ho- mogenous cell distribution can be achieved upon polymerisation.

As fibrous long-spacing collagen provides most of mechanical and tensile strength of the heart valve, a valve construct fabricated using a natural collagen scaffold is quite a logical choice. Collagens are weakly immunogenic compared to other structural proteins, due to a large degree of homology across species, and are biodegradable on account of their proteinaceous nature (Chevallay and Herbage, 2000). Collagen scaffolds have been investigated for the production of heart valve-like tissue using human and porcine-derived cells (Rothenburger et al., 2001; Flanagan et al., 2002; Taylor et al., 2002). Rothenburger and colleagues used a cryogenically-engineered collagen type I matrix derived from bovine skin tissue, with a homogenous pore size of $40 \mu \mathrm{m}$ and a porosity of $98 \%$. The matrix was cut into disc structures and sequentially seeded with either human or porcine aortic smooth muscle cells. The structures were then seeded with porcine aortic endothelial cells and maintained in culture for 28 days. A tissue-like morphology was observed in all samples, characterised by several layers of cells with newly synthesised ECM components. Proteoglycans and the ECM proteins fibronectin and thrombospondin were also localised.

Ye and colleagues (2000b) took another approach to the construction of tissue using 'natural' materials by producing completely human autogeneic tissue without the use of a supporting scaffold. Myofibroblasts were cultured in large culture dishes in medium supplemented with L-ascorbic acid 2-phospate to promote extracellular matrix production. The cell sheets subsequently formed were folded into quadrilaminar sheets and mounted on customised culture frames. They were then cultured for a further 4 weeks and demonstrated a multilayer tissue pattern, with active viable cells surrounded by extracellular matrix.

Adequate, uniform and reproducible cell seeding of both natural and synthetic polymeric scaffolds remains a difficulty in the field. In an effort to improve scaffold cell-seeding methods, Ye and colleagues (2000c) have demonstrated the possibility of coating scaffolds with an autologous immuno-compatible ECM material; Zund and colleagues (1999) aimed to improve cell-seeding methods by optimising the cell seeding interval (i.e. the length of time between subsequent seeding procedures). Their results suggest that longer seeding intervals of 24- to 36-hours result in higher cell attachment and cell growth on PGA scaffolds, this may have been due to 'pre-conditioning' of the seeded scaffolds by cells previously laid down. Optimisation of rapid seeding techniques will be important in LAHVA fabrication, as it maximises the use of donor cells, hastens the proliferation and subsequent differentiation of cells, decreases the time in culture, and provides a uniform distribution of cells (Vunjak-Novakovic et al., 1998). Advances in the modification of scaffold surfaces to enhance cell adhesion and subsequent function will be necessary for short-term ex vivo culture of tissues prior to implantation.

It is not clear whether natural or synthetic scaffolds will ultimately prove to be more appropriate for LAHVA development, as there are still certain limitations associated with both. The optimum heart valve scaffold should display an 
accurate, anatomical spatial reconstruction of the valve to be replaced. The design of a replacement aortic valved-conduit, for example, will require the inclusion of three dilated pouches alongside the 'cusp-like' leaflets to approximate the sinuses of Valsalva; $\mathrm{AV}$ valve designs may require the addition of other components of the AV valve apparatus, including chordae tendineae and papillary muscles (Bursac et al., 1999; Zimmermann et al., 2002). Using stereolithography, Sodian and colleagues (2002) fabricated plastic models with an exact spatial representation of human aortic and pulmonary valve. These models were then used to fabricate heart valve cell scaffolds using poly-3hydroxyoctanoate-co-3-hydroxyhexanoate $(\mathrm{PHOH})$ and $\mathrm{P} 4 \mathrm{HB}$, which were shown to function well in a pulsatile flow bioreactor under both normal and supranormal flow and pressure conditions. The choice and design of scaffolds will be integral to the successful clinical outcome of a LAHVA. As well as conforming to a suitable anatomical shape, heart valve scaffolds will be required to possess both tensile and elastic properties. The scaffolds should be biocompatible, bioabsorbable or remodelable, and should provide a suitable template for facilitating development of new tissue. Scaffold permeability is also vital for the control of cell nutrition and removal of waste products.

\section{Signalling factors investigated in LAHVA development}

There is a dearth of research into the application of growth factors, mitogenic factors or adhesion factors in scaffolds and matrices used to develop a LAHVA. However, significant progress has been made in the development of in vitro methods of mechanical stimulation or physical signalling to improve cell and tissue growth prior to implantation (Hoerstrup et al., 1999; Weston et al., 1999; Hoerstrup et al., 2000b; Sodian et al., 2001; Weston and Yoganathan, 2001; Zeltinger et al., 2001; Jockenhoevel et al., 2002; Dumont et al., 2002; Perry et al., 2003; Engelmayr et al., 2003).

One method of mechanically stimulating cells to induce tissue morphogenesis is maintaining them in culture under isometric strain (Stopak and Harris, 1982). A number of groups report increased collagen synthesis and tissue organisation in LAHVA scaffolds mounted in cultures frames that provide isometric strain (Hoerstrup et al., 1999), border-fixed fibrin gel structures (Jockenhoevel et al., 2001b) and cyclically-strained scaffolds (Mol et al., 2003).

The mechanical properties obtained by Niklason et al. with tissue-engineered vascular constructs cultured under pulsatile flow conditions (Niklason et al., 1999) prompted a number of other investigators to develop bioreactor systems to improve the mechanical structure of LAHVAs. Jockenhoevel and colleagues designed and constructed a flow system to investigate the effects of laminar flow conditions on ECM formation and tissue development in cellseeded synthetic biodegradable polymer scaffolds (Jockenhoevel et al., 2002). The system was efficient at maintaining sterile culture conditions, and extracellular matrix production was significantly higher than static controls. Current experiments in the design and development of a system specific for dynamic culture of fibrin and col- lagen gel LAHVA structures are ongoing (Flanagan and Jockenhoevel, unpublished results).

Pulsatile flow systems have also been engineered to condition both myocardial patch tissue and trileaflet heart valve tissue in vitro (Hoerstrup et al., 2000b; Sodian et al., 2001). The pulse duplicator system of Hoerstrup and colleagues was designed to grow LAHVAs under gradually increasing flow and pressure conditions in order to mirror the physical stimulation encountered in vivo (Hoerstrup et al., 2000b). The conditioned structures demonstrated a much higher deposition of ECM, improved tissue organisation and better mechanical properties than those grown in static conditions. Zeltinger et al. (2001) demonstrated efficient colonisation of decellularised porcine valve scaffolds with human dermal fibroblasts using a pneumatic flow bioreactor apparatus. The application of pulsatile fluid flow was shown to stimulate ECM production and cell proliferation, improving the structural integrity of the LAHVA.

A major drawback with all of these pulsatile flow systems, however, is the limit to the number of test samples (i.e. only one LAHVA sample can be conditioned at a time), which does not offer statistically significant results. Results are also limited to a combination of mechanical stimuli, rather than observing the effects of single stimuli, such as laminar shear and isometric tension studies previously undertaken (Hoerstrup et al., 1999; Jockenhoevel et al., 2002). A recent bioreactor design allowed studies of the effects of cyclic three-point flexure on LAHVA structures, and incorporated a large test sample size to demonstrate significant results (Engelmayr et al., 2003). The investigators report fatigue and fracture in acellular biodegradable polymer scaffolds cultured under dynamic flexure conditions; this may prove to have important consequences in the design and selection of potential LAHVA scaffold candidates.

Although significant progress has been made, all LAHVAs constructed to date lack the mechanical strength required for functional performance in the anatomical position. All previous studies have been directed towards the design of LAHVAs for transplantation at the low-pressure pulmonary valve site. A clearer understanding of the mechanical environment of all four heart valves, in particular those of the systemic circulation, will lead to the development and production of improved biomimetic environments for the in vitro pre-conditioning of LAHVAs. Cell response mechanisms to mechanical stimuli are unclear (MacKenna et al., 2000) and a better understanding will permit the design of more efficient biomimetic protocols. Cell death caused by dynamic bioreactor culture conditions will also need to be investigated, and conditions optimised to minimise cell death. Gene therapy studies have the potential to be exploited in order to promote the expression of suitable mitogenic, angiogenic or neurogenic factors in a LAHVA (Yla-Herttuala and Martin, 2000; Musgrave et al., 2002) to enhance development of a more 'native' heart valve tissue in concert with mechanical stimulation studies. 


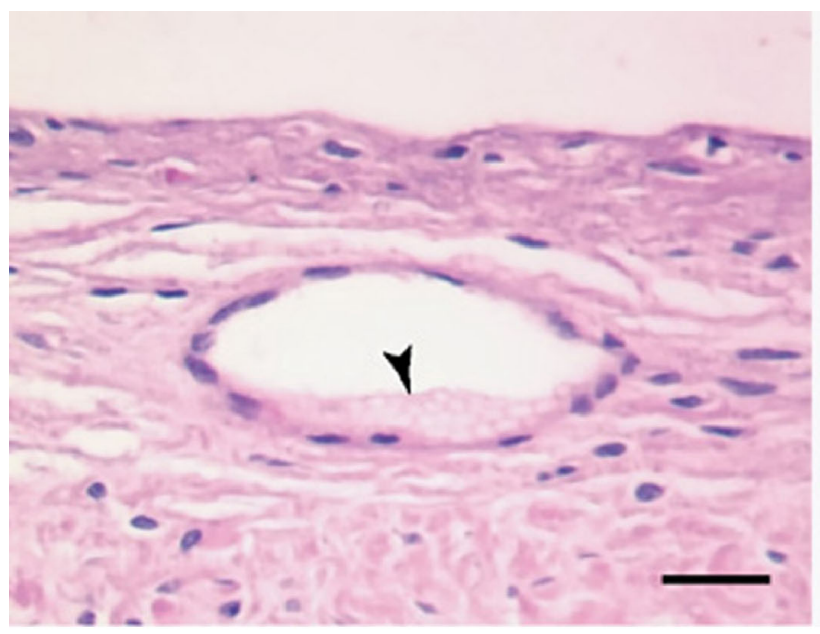

$3 \mathrm{a}$

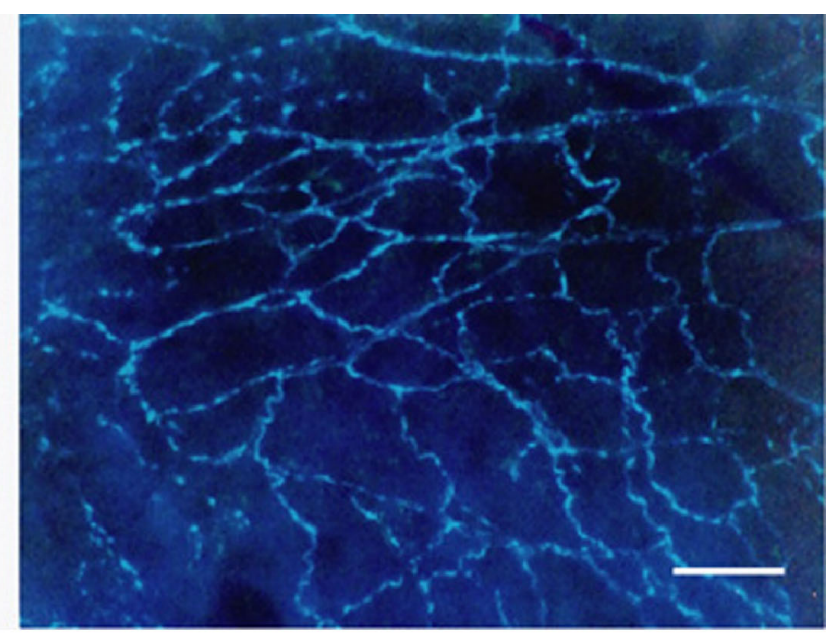

$3 b$

Figure 3 Both vascular elements (a) and neural elements (b) have been demonstrated in the heart valve interstitial matrix: (a) blood vessel embedded in the atrialis/spongiosa layer of the porcine mitral valve containing red blood cells (arrowhead) (haematoxylin \& eosin staining). Scale bar 50 $\mu \mathrm{m}$; (b) dense adrenergic nerve plexus situated in the anterior leaflet of the rat mitral valve (sucrose-potassium phosphate-glyoxylic acid staining). Scale bar $30 \mu \mathrm{m}$.

\section{Conclusion}

Heart valve tissue engineering holds great promise for improved treatment of valve disease. Significant advances have been made since its inception in the early 1990s, however, the field remains in its infancy and many issues remain to be addressed and resolved. Primary amongst these is our limited understanding of the normal heart valve, in particular normal valvar cell biology (including gene expression and regulation) and normal valvar ECM composition. A blueprint for LAHVA fabrication can only be achieved through substantial advances in our understanding of basic heart valve biology. Identification of the appropriate transplantation cell types and scaffolds remain the key strategies. Data concerning VECs remains limited, thus characterisation of these cells may take precedence over that of VICs. Furthermore, the presence of vascular (Figure 3a) and in particular neural elements (Figure $3 b$ ) in the AV valves requires further research to determine their role in normal valve function. It may be possible to control vascularisation and neurogenesis in a LAHVA by investigating, characterising and incorporating angiogenic and neurogenic factors. A thorough understanding of embryonic and fetal heart valve development may permit the control of heart valve tissue morphogenesis both in vitro and in vivo. As developmental studies improve, the field should acquire an improved understanding of the mechanisms that may allow for reproducible construction of clinically acceptable heart valves ex vivo. It would also allow accurate predictions about valvar morphogenic events under specified conditions, allowing advances to be made in the design and development of suitable bioreactor systems. Other key technological advances are required to enable the transition from experimental model to clinical reality, and will require the cooperation of researchers from a broad spectrum of disciplines. Consistent manufacture of LAHVAs and adequate assessment standards will pose equally challenging factors in this exciting area of research.

\section{Acknowledgements}

The authors wish to express their sincere gratitude to Alexander Black of the Department of Anatomy, NUI Galway, for his expert advice and critical review of the manuscript. In addition, TCF gratefully acknowledges Enterprise Ireland (EI), the Deutscher Akademischer Austausch Dienst (DAAD), the Faculty of Science NUIG and the National Centre for Biomedical Engineering Science NUIG for financial support of his doctoral research.

\section{References}

Ahmed A, Johansson O, Folan-Curran J (1996) Distribution of PGP 9.5, TH, NPY, SP and CGRP immunoreactive nerves in the rat and guinea pig atrioventricular valves and chordae tendineae. J Anat 191: 547-560.

al-Khaja N, Belboul A, Rashid M, el-Gatit A, Roberts D, Larsson S, William-Olsson G (1991) The influence of age on the durability of Carpentier-Edwards biological valves. Thirteen years follow-up. Eur J Cardiothorac Surg 5: $635-640$.

Alvarez J, Murday A (1995) Mitral valve repair. Br J Hosp Med 53: 221-225.

American Heart Association (2002) Heart Disease and Stroke Statistics - 2003 Update. Dallas, Texas: American Heart Association.

Angell WW, Oury JH, Lamberti JJ, Koziol J (1989) Durability of the viable aortic allograft. J Thorac Cardiovasc Surg 98: 48-55.

Bachetti T, Morbidelli L (2000) Endothelial cells in culture: a model for studying vascular function. Pharmacol Res 42: 9-19.

Bader A, Schilling T, Teebken OE, Brandes G, Herden T, Steinhoff G, Haverich A (1998) Tissue engineering of heart valves - human endothelial cell seeding of detergent acellularised porcine valves. Eur J Cardiothorac Surg 14: 279-284. 
Badylak SF, Lantz GC, Coffey A, Geddes LA (1989) Small intestinal submucosa as a large diameter vascular graft in the dog. J Surg Res 47: 74-80.

Badylak SF, Record R, Lindberg K, Hodde J, Park K (1998) Small intestinal submucosa: a substrate for in vitro cell growth. J Biomater Sci Polym Ed 9: 863-878.

Barron V, Lyons E, Stenson-Cox C, McHugh PE, Pandit A (2003) Bioreactors for cardiovascular cell and tissue growth: a review. Ann Biomed Eng 31: 1017-1030.

Batten P, McCormack AM, Rose ML, Yacoub MH (2001) Valve interstitial cells induce donor-specific T-cell anergy. J Thorac Cardiovasc Surg 122: 129-135.

Bertipaglia B, Ortolani F, Petrelli L, Gerosa G, Spina M, Pauletto P, Casarotto D, Marchini M, Sartore S (2003) Cell characterisation of porcine aortic valve and decellularised leaflets repopulated with aortic valve interstitial cells: the VESALIO project (Vitalitate Exornatum Succedaneum Aorticum Labore Ingenioso Obtenibitur). Ann Thorac Surg 75: 1274-1282.

Booth C, Korossis SA, Wilcox HE, Watterson KG, Kearney JN, Fisher J, Ingham E (2002) Tissue engineering of cardiac valve prostheses I: development and histological characterisation of an acellular porcine scaffold. J Heart Valve Dis 11: 457-462.

Breuer CK, Shinoka T, Tanel RE, Zund G, Mooney DJ, Ma PX, Miura T, Colan S, Langer R, Mayer JE Jr, Vacanti JP (1996) Tissue engineering lamb heart valve leaflets. Biotech Bioeng 50: 562-567.

Bursac N, Papadaki M, Cohen RJ, Schoen FJ, Eisenberg SR, Carrier R, Vunjak-Novakovic G, Freed LE (1999) Cardiac muscle tissue engineering: toward an in vitro model for electrophysiological studies. Am J Physiol 277: H433H444.

Butany J, Ahluwalia MS, Munroe C, Fayet C, Ahn C, Blit P, Kepron C, Cusimano RJ, Leask RL (2003a) Mechanical heart valve prostheses: identification and evaluation. Cardiovasc Pathol 12: 1-22.

Butany J, Fayet C, Ahluwalia MS, Blit P, Ahn C, Munroe C, Israel N, Cusimano RJ, Leask RL (2003b) Biological replacement heart valves: identification and evaluation. Cardiovasc Pathol 12: 119-139.

Caplan AI, Bruder SP (2001) Mesenchymal stem cells: building blocks for molecular medicine in the $21^{\text {st }}$ century. Trends Mol Med 7: 259-264.

Carabello BA, Crawford FA Jr (1997) Valvular heart disease. N Engl J Med 337: 32-41.

Chapekar MS (2000) Tissue engineering: challenges and opportunities. J Biomed Mater Res 53: 617-620.

Chester AH, Misfeld M, Yacoub MH (2000) Receptormediated contraction of aortic valve leaflets. J Heart Valve Dis 9: 250-254.

Chester AH, Misfeld M, Sievers HH, Yacoub MH (2001) Influence of 5-hydroxytryptamine on aortic valve competence in vitro. J Heart Valve Dis 10: 822-825.

Chevallay B, Herbage D (2000) Collagen-based biomaterials as 3D scaffold for cell cultures: applications for tissue engineering and gene therapy. Med Biol Eng Comput 38: 211-218.

Christov AM, Liu L, Lowe S, Icton C, Dunmore-Buyze J, Boughner DR, Dai E, Lucas A (1999) Laser-induced fluorescence (LIF) recognition of the structural composition of porcine heart valves. Photochem Photobiol 69: 382-389.

Cole WG, Chan D, Hickey AJ, Wilcken DE (1984) Collagen composition of normal and myxomatous human mitral heart valves. Biochem J 219: 451-460.

Cooper T, Napolitano LM, Fitzgerald MJT, Moore KE, Daggett WM, Willman VL, Sonnenblick EH, Hanlon CR (1966) Structural basis of cardiac valvar function. Arch Surg 93: 767-771.

Culav EM, Clark CH, Merrilees MJ (1999) Connective tissues: matrix composition and its relevance to physical therapy. Phys Ther 79: 308-319.

Curcio CA, Commerford PJ, Rose AG, Stevens JE, Barnard MS (1981) Calcification of glutaraldehyde-preserved porcine xenografts in young patients. J Thorac Cardiovasc Surg 81: 621-625.

Dreger SA, Taylor PM, Allen SP, Yacoub MH (2002) Profile and localisation of matrix metalloproteinases (MMPs) and their tissue inhibitors (TIMPs) in human heart valves. J Heart Valve Dis 11: 875-880.

Dumont K, Yperman J, Verbeken E, Segers P, Meuris B, Vandenberghe S, Flameng W, Verdonck PR (2002) Design of a new pulsatile bioreactor for tissue engineered aortic heart valve formation. Artif Organs 28: 710-714.

Eisenberg LM, Markwald RR (1995) Molecular regulation of atrioventricular valvuloseptal morphogenesis. Circ Res 77: 1-6.

Engelmayr GC Jr, Hildebrand DK, Sutherland FWH, Mayer JE Jr, Sacks MS (2003) A novel bioreactor for the dynamic flexural stimulation of tissue engineered heart valve biomaterials. Biomaterials 24: 2523-2532.

Eyden BP, Ponting J, Davies H, Bartley C, Torgersen E (1994) Defining the myofibroblast: normal tissues, with respect to the stromal cells of Wharton's jelly in human umbilical cord. J Submicrosc Cytol Pathol 26: 347-355.

Fenoglio JJ, Pham TD, Wit AL, Bassett AL, Wagner BM (1972) Canine mitral complex: ultrastructure and electromechanical properties. Circ Res 31: 417-430.

Filip DA (1984) Mouse atrio-ventricular valve ultrastructure. Morphometrical correlations. Morphol Embryol 30: 165-173.

Filip DA, Radu A, Simionescu M (1986) Interstitial cells of the heart valves possess characteristics similar to smooth muscle cells. Circ Res 59: 310-320.

Flanagan TC, Mulvihill A, Black A, Wilkins B (2002) In vitro construction of viable, functional tissue derived from mammalian heart valve using a natural extracellular matrix scaffold. Suppl Proc Royal Micros Soc 37(4): 910. (Abstract). http://www.nuigalway.ie/msi/docs/2002.pdf

Flanagan TC, Mulvihill A, Wilkins B, Black A, Jockenhoevel S, Pandit A (2003) Characterisation of mitral valve interstitial cells and endocardial cells in 2-D- and 3-D-culture. Int J Artif Organs 26: 584. (Abstract).

Frater RWM, Gong G, Hoffman D, Liao K (1992) Endothelial covering of biological artificial heart valves. Ann Thorac Surg 53: 371-372.

Fuchs JR, Nasseri BA, Vacanti JP (2001) Tissue engineering: a 21 st century solution to surgical reconstruction. Ann Thorac Surg 72: 577-591.

Galis ZS, Khatri JJ (2002) Matrix metalloproteinases in vascular remodelling and atherogenesis: the good, the bad, and the ugly. Circ Res 90: 251-262. 
Garcia-Martinez V, Hurle JM (1986) Cell shape and cytoskeletal organization of the endothelial cells of the semilunar heart valves in the developing chick. Anat Embryol 174: 83-89.

Grassl ED, Oegema TR, Tranquillo RT (2002) Fibrin as an alternative biopolymer to type-I collagen for the fabrication of a media equivalent. J Biomed Mater Res 60: 607-612.

Grinnell F, Fukamizu H, Pawelek P, Nakagawa S (1989) Collagen processing, crosslinking and fibril bundle assembly in matrix produced by fibroblasts in long-term culture supplemented with ascorbic acid. Exp Cell Res 181: 483 491.

Gross L, Kugel MA (1931) Topographic anatomy and histology of the valves in the human heart. Am J Path 7: 445-456.

Guarda E, Myers PR, Brilla CG, Tyagi SC, Weber KT (1993) Endothelial cell induced modulation of fibroblast collagen metabolism. Cardiovasc Res 27: 1004-1008.

Hafizi S, Taylor PM, Chester AH, Allen SP, Yacoub MH (2000) Mitogenic and secretory responses of human valve interstitial cells to vasoactive agents. J Heart Valve Dis 9: 454-458.

Hammermeister KE, Sethi GK, Henderson WG, Oprian C, Kim T, Rahimtoola S (1993) A comparison of outcomes in men 11 years after heart-valve replacement with a mechanical valve or bioprosthesis. N Engl J Med 328: 12891296.

Harasaki H, Suzuki I, Tanaka J, Hanano H, Torisu M (1975) Ultrastructure research of the endocardial endothelium of monkeys. Arch Histol Jpn 38: 71-84.

Heath CA (2000) Cells for tissue engineering. Trends Biotechnol 18: 17-19.

Henney AM, Parker DJ, Davies MJ (1982) Collagen biosynthesis in normal and abnormal human heart valves. Cardiovasc Res 16: 624-630.

Hibbs RG, Ellison JP (1973) The atrioventricular valves of the guinea-pig. II. An ultrastructural study. Am J Anat 138: $347-369$.

Hill AD, Folan-Curran J (1993) Microappendages on the atrioventricular valves of the guinea pig. J Anat 182: 425-428.

Hoerstrup SP, Zund G, Ye Q, Schoeberlein A, Schmid AC, Turina MI (1999) Tissue engineering of a bioprosthetic heart valve: stimulation of extracellular matrix assessed by hydroxyproline assay. ASAIO J 45: 397-402.

Hoerstrup SP, Sodian R, Daebritz S, Wang J, Bacha EA, Martin DP, Moran AM, Guleserian KJ, Sperling JS, Kaushal S, Vacanti JP, Schoen FJ, Mayer JE Jr (2000a) Functional trileaflet heart valves grown in vitro. Circulation 102(suppl III): III-44-III-49.

Hoerstrup SP, Sodian R, Sperling JS, Vacanti JP, Mayer JE Jr (2000b) New pulsatile bioreactor for in vitro formation of tissue engineered heart valves. Tissue Eng 6: 7579.

Hoerstrup SP, Kadner A, Meknitchouk S, Trojan A, Eid K, Tracy J, Sodian R, Visjager JF, Kold SA, Grunenfelder J, Zund G, Turina M (2002) Tissue engineering of functional trileaflet heart valves from human marrow stromal cells. Circulation 106(suppl I): I-143-I-150.

Hubbell JA (1995) Biomaterials in tissue engineering.
Biotechnology 13: 565-576.

Hufnagel CA, Harvey WP, Rabil PJ, McDermott TF (1952) Surgical correction of aortic insufficiency. Surgery 35: 673-683.

Hurle M, Colvee E, Fernandez-Teran MA (1985) The surface anatomy of the human aortic valve as revealed by scanning electron microscopy. Anat Embryol 172: 61-67.

Jockenhoevel S, Chalabi K, Sachweh J, Groesdonk HV, Demircan L, Grossmann M, Zund G, Messmer BJ (2001a) Tissue engineering: complete autologous valve conduit a new moulding technique. Thorac Cardiovasc Surg 49: 287-290.

Jockenhoevel S, Zund G, Hoerstrup SP, Chalabi K, Sachweh JS, Demircan L, Messmer BJ, Turina M (2001b) Fibrin gel - advantages of a new scaffold in cardiovascular tissue engineering. Eur J Cardiothorac Surg 19: 424-430.

Jockenhoevel S, Zund G, Hoerstrup SP, Schnell A, Turina M (2002) Cardiovascular tissue engineering: a new laminar flow chamber for in vitro improvement of mechanical tissue properties. ASAIO J 48: 8-11.

Johnson CM, Hanson MN, Nelgeson SC (1987) Porcine cardiac valvular sub-endothelial cells in culture : cell isolation and growth characteristics. J Mol Cell Cardiol 19: 1185-1193.

Kadner A, Hoerstrup SP, Tracy J, Breymann C, Maurus CF, Melnitchouk S, Kadner G, Zund G, Turina M (2002a) Human umbilical cord cells: a new cell source for cardiovascular tissue engineering. Ann Thorac Surg 74: S1422S1428.

Kadner A, Hoerstrup SP, Zund G, Eid K, Maurus C, Melnitchouk S, Grunenfelder J, Turina MI (2002b) A new source for cardiovascular tissue engineering: human bone marrow stromal cells. Eur J Cardiothorac Surg 21: 10551060 .

Kim BS, Mooney DJ (1998) Development of biocompatible synthetic extracellular matrices for tissue engineering. Trends Biotechnol 16: 224-230.

Kim WG, Cho SK, Kang M-C, Lee T-Y, Park JK (2001) Tissue-engineered heart valve leaflets: an animal study. Int J Artif Organs 24: 642-648.

Korossis SA, Fisher J, Ingham E (2000) Cardiac valve replacement: a bioengineering approach. Biomed Mater Eng 10: 83-124.

Kunzelman KS, Cochran RP, Murphree SS, Ring WS, Verrier ED, Eberhart RC (1993) Differential collagen distribution in the mitral valve and its influence on biomechanical behaviour. J Heart Valve Dis 2: 236-244.

Langer R, Vacanti JP (1993) Tissue engineering. Science 260: 920-926.

Langer R, Vacanti JP (1999) Tissue engineering: the challenges ahead. Sci Am 280: 86-89.

Lehner G, Fischlein T, Baretton G, Murphy JG, Reichart B (1997) Endothelialized biological heart valve prostheses in the non-human primate model. Eur J Cardiothorac Surg 11: 498-504.

Lester WM, Rosenthal A, Granton B, Gotlieb AI (1988) Porcine mitral valve interstitial cells in culture. Lab Invest 59: 710-719.

Lester WM, Damji AA, Gedeon I, Tanaka M (1993) Interstitial cells from the atrial and ventricular sides of the bovine mitral valve respond differently to denuding endo- 
cardial injury. In Vitro Cell Dev Biol 29A: 41-50.

Lupu F, Simionescu M (1985) Organisation of the intercellular junctions in the endothelium of cardiac valves. $\mathrm{J}$ Submicrosc Cytol 17: 119-132.

MacKenna D, Summerour SR, Villarreal FJ (2000) Role of mechanical factors in modulating cardiac fibroblast function and extracellular matrix synthesis. Cardiovasc Res 46: 257-263.

Maish MS, Hoffman-Kim D, Krueger PM, Souza JM, Harper JJ $3^{\text {rd }}$, Hopkins RA (2003) Tricuspid valve biopsy: a potential source of cardiac myofibroblast cells for tissue-engineered cardiac valves. J Heart Valve Dis 12: $264-$ 269.

Manduteanu I, Popov D, Radu A, Simionescu M (1988) Calf cardiac valvular endothelial cells in culture: production of glycosaminoglycans, prostacyclin and fibronectin. J Mol Cell Cardiol 20: 103-118.

Mann BK, West JL (2001) Tissue engineering in the cardiovascular system: progress toward a tissue engineered heart. Anat Rec 263: 367-371.

Marron K, Yacoub MH, Polak JM, Sheppard MN, Fagan D, Whitehead BF, de Leval MR, Anderson RH, Wharton J (1996) Innervation of human atrioventricular and arterial valves. Circulation 94: 368-375.

Martin DP, Williams SF (2003) Medical applications of poly-4-hydroxybutyrate: a string flexible absorbable material. Biochem Eng J 3738: 1-9.

Matheny RG, Hutchison ML, Dryden PE, Hiles MD, Shaar CJ (2000) Porcine small intestinal submucosa as a pulmonary valve leaflet substitute. J Heart Valve Dis 9: 769-774.

McCawley LJ, Matrisian LM (2001) Matrix metalloproteinases: they're not just for matrix anymore! Curr Opin Cell Biol 13: 534-540.

Messier RH, Bass BL, Aly HM, Jones JL, Domkowski PW, Wallace RB, Hopkins RA (1994) Dual structural and functional characteristics of the porcine aortic valve interstitial population: characteristics of the leaflet myofibroblast. J Surg Res 57: 1-21.

Misfeld M, Morrison K, Sievers H, Yacoub MH, Chester AH (2002) Localisation of immunoreactive endothelin and characterisation of its receptors in aortic cusps. J Heart Valve Dis 11: 472-476.

Missirlis YF, Armeniades CD (1977) Ultrastructure of the human aortic valve. Acta Anat 98: 199-205.

Mitchell RN, Jonas RA, Schoen FJ (1995) Structurefunction correlations in cryopreserved allograft cardiac valves. Ann Thorac Surg 60: S108-S113.

Mol A, Bouten CV, Zund G, Gunter CI, Visjager JF, Turina MI, Baaijens FP, Hoerstrup SP (2003) The relevance of large strains in functional tissue engineering of heart valves. Thorac Cardiovasc Surg 51: 78-83.

Mulholland DL, Gotlieb AI (1997) Cardiac valve interstitial cells: regulator of valve structure and function. Cardiovasc Pathol 6: 167-174.

Murata K (1981) Acidic glycosaminoglycans in human heart valves. J Mol Cell Cardiol 13: 281-292.

Musgrave DS, Fu FH, Huard J (2002) Gene therapy and tissue engineering in orthopaedic surgery. J Am Acad Orthop Surg 10: 6-15.

Neidert MR, Lee ES, Oegema TR, Tranquillo RT (2002)
Enhanced fibrin remodelling in vitro with TGF-beta 1, insulin and plasmin for improved tissue-equivalents. Biomaterials 23: 3717-3731.

Nelson AR, Fingleton B, Rothenberg ML, Matrisian LM (2000) Matrix metalloproteinases: biologic activity and clinical implications. J Clin Oncol 18: 1135-1149.

Nerem RM, Seliktar D (2001) Vascular tissue engineering. Annu Rev Biomed Eng 3: 225-243.

Niklason LE, Gao J, Abbott WM, Hirschi KK, Houser S, Marini R, Langer R (1999) Functional arteries grown in vitro. Science 284: 489-493.

Nugent HM, Edelman ER (2003) Tissue engineering therapy for cardiovascular disease. Circ Res 92: 1068-1078.

O’Brien MF, Goldstein S, Walsh S, Black KS, Elkins R, Clarke D (1999) The SynerGraft valve: a new acellular (non-glutaraldehyde-fixed) tissue heart valve for antilogous recellularisation. First experimental studies before clinical implantation. Semin Thorac Cardiovasc Surg 11(4 suppl 1): 194-200.

Pandit AS, Wilson DJ, Feldman DS (2000) Fibrin scaffold as an effective vehicle for the delivery of acidic fibroblast growth factor (FGF-1). J Biomater Appl 14: 229242.

Perry TE, Kaushal S, Sutherland FWH, Guleserian KJ, Bischoff J, Sacks M, Mayer JE (2003) Bone marrow as a cell source for tissue engineering heart valves. Ann Thorac Surg 75: 761-767.

Pittenger MF, Mackay AM, Beck SC, Jaiswal RK, Douglas R, Mosca JD, Moorman MA, Simonetti DW, Craig S, Marshak DR (1999) Multilineage potential of adult human mesenchymal stem cells. Science 284: 143-147.

Putnam AJ, Mooney DJ (1996) Tissue engineering using synthetic extracellular matrices. Nat Med 2: 824-826.

Rabkin E, Schoen FJ (2002) Cardiovascular tissue engineering. Cardiovasc Pathol 11: 305-317.

Rabkin E, Aikawa M, Stone JR, Fukumoto Y, Libby P, Schoen FJ (2001) Activated interstitial myofibroblasts express catabolic enzymes and mediate matrix remodeling in myxomatous heart valves. Circulation 104: 2525-2532.

Rafii S (2000) Circulating endothelial precursors: mystery, reality, and promise. J Clin Invest 105: 17-19.

Rajamannan NM, Springett MJ, Pederson LG, Carmichael SW (2002) Localisation of caveolin 1 in aortic valve endothelial cells using antigen retrieval. J Histochem Cytochem 50: 617-628.

Rajani B, Mee RB, Ratliff NB (1998) Evidence for rejection of homograft cardiac valves in infants. J Thorac Cardiovasc Surg 115: 111-117.

Rothenburger M, Vischer P, Volker W, Glasmacher B, Berendes E, Scheld HH, Deiwick M (2001) In vitro modelling of tissue using isolated vascular cells on a synthetic collagen matrix as a substitute for heart valves. Thorac Cardiov Surg 49: 204-209.

Roy A, Brand NJ, Yacoub MH (2000) Molecular characterisation of interstitial cells isolated from human heart valves. J Heart Valve Dis 9: 459-464.

Sastry SK, Burridge K (2000) Focal adhesions: a nexus for intracellular signaling and cytoskeletal dynamics. Exp Cell Res 261: 25-36.

Schmidt CE, Baier JM (2000) Acellular vascular tissues: natural biomaterials for tissue repair and tissue engi- 
neering. Biomaterials 21: 2215-2231.

Schneider PJ, Deck JD (1981) Tissue and cell renewal in the natural aortic valve of rats: an autoradiographic study. Cardiovasc Res 15: 181-189.

Schnell AM, Hoerstrup SP, Zund G, Kold S, Sodian R, Visjager JF, Grunenfelder J, Suter A, Turina M (2001) Optimal cell source for cardiovascular tissue engineering: venous vs. aortic human myofibroblasts. Thorac Cardiovasc Surg 49: 221-225.

Schoen FJ, Levy RJ (1994) Pathology of substitute heart valves: new concepts and developments. J Card Surg 9(suppl): 222-227.

Schoen FJ, Levy RJ (1999) Tissue heart valves: current challenges and future research perspectives. J Biomed Mater Res 47: 439-465.

Schoen FJ, Levy RJ, Nelson AC, Bernhard WF, Nashef A, Hawley M (1985) Onset and progression of experimental bioprosthetic heart valve calcification. Lab Invest 52: 523-532.

Scott M, Vesely I (1995) Aortic valve cusp microstructure: the role of elastin. Ann Thorac Surg 60: S391-S394.

Shinoka T, Breuer CK, Tanel RE, Zund G, Miura T, Ma PX, Langer R, Vacanti JP, Mayer JE Jr (1995) Tissue engineered heart valves: valve leaflet replacement study in lamb model. Ann Thorac Surg 60: S513-S516.

Shinoka T, Ma PX, Shum-Tim D, Breuer CK, Cusick RA, Zund G, Langer R, Vacanti JP, Mayer JE Jr (1996) Tissue-engineered heart valves: autologous valve leaflet replacement study in a lamb model. Circulation 94(suppl II): II-164-II-168.

Shinoka T, Shum-Tim D, Ma PX, Tanel RE, Langer R, Vacanti JP, Mayer JE Jr (1997) Tissue-engineered heart valve leaflets: does cell origin affect outcome? Circulation 96(suppl II): II-102-II-107.

Simon A, Zavazava N, Sievers HH, Muller-Ruchholtz $\mathrm{W}$ (1993) In vitro cultivation and immunogenicity of human cardiac valve endothelium. J Card Surg 8: 656-665.

Simon P, Kasimir MT, Seebacher G, Weigel G, Ullrich R, Salzer-Muhar U, Rieder E, Wolner E (2003) Early failure of the tissue engineered porcine heart valve SYNERGRAFT ${ }^{\mathrm{TM}}$ in pediatric patients. Eur J Cardiothorac Surg 23: 1002-1006.

Simper D, Stalboerger PG, Panetta CJ, Wang S, Caplice NM (2002) Smooth muscle progenitor cells in human blood. Circulation 106: 1199-1204.

Siney L, Lewis MJ (1993) Nitric oxide release from porcine mitral valves. Cardiovasc Res 27: 1657-1661.

Smith JA, Radomski MW, Schulz R, Moncada S, Lewis MJ (1993) Porcine ventricular endocardial cells in culture express the inducible form of nitric oxide synthase. Br J Pharmacol 108: 1107-1110.

Sodian R, Sperling JS, Martin DP, Egozy A, Stock U, Mayer JE Jr, Vacanti JP (2000a) Fabrication of a trileaflet heart valve scaffold from a polyhydroxyalkanoate biopolyester for use in tissue engineering. Tissue Eng 6: 183-188.

Sodian R, Hoerstrup SP, Sperling JS, Daebritz S, Martin DP, Schoen FJ, Vacanti JP, Mayer JE Jr (2000b) Tissue engineering of heart valves: in vitro experiences. Ann Thorac Surg 70: 140-144.

Sodian R, Lemke T, Loebe M, Hoerstrup SP, Potapov
EV, Hausmann H, Meyer R, Hetzer R (2001) New pulsatile bioreactor for fabrication of tissue-engineered patches. $\mathrm{J}$ Biomed Mater Res 58: 401-405.

Sodian R, Loebe M, Hein A, Martin DP, Hoerstrup SP, Potapov EV, Hausmann H, Leuth T, Hetzer R (2002) Application of stereolithography for scaffold fabrication for tissue engineered heart valves. ASAIO J 48: 12-16.

Steinhoff G, Stock U, Karim N, Mertsching H, Timke A, Meliss RR, Pethig K, Haverich A, Bader A (2000) Tissue engineering of pulmonary heart valves on allogenic acellular matrix conduits: in vivo restoration of valve tissue. Circulation 102(suppl III): III-50-III-55.

Stock UA, Nagashima M, Khalil PN, Nollert GD, Herden T, Sperling JS, Moran A, Lien J, Martin DP, Schoen FJ, Vacanti JP, Mayer JE Jr (2000) Tissue-engineered valved conduits in the pulmonary circulation. J Thorac Cardiovasc Surg 119: 732-740.

Stopak D, Harris AK (1982) Connective tissue morphogenesis by fibroblast traction. I. Tissue culture observations. Dev Biol 90: 383-398.

Tabata Y (2000) The importance of drug delivery systems in tissue engineering. Pharm Sci Technol Today 3: 8089.

Taylor PM, Allen SP, Yacoub MH (2000) Phenotypic and functional characterization of interstitial cells from human heart valves, pericardium and skin. J Heart Valve Dis 9: $150-158$.

Taylor PM, Allen SP, Dreger SA, Yacoub MH (2002) Human cardiac valve interstitial cells in collagen sponge: a biological three-dimensional matrix for tissue engineering. J Heart Valve Dis 11: 298-307.

Vacanti JP, Langer R (1999) Tissue engineering: the design and fabrication of living replacement devices for surgical reconstruction and transplantation. Lancet 354 (suppl I): $32-34$.

Valente M, Bortolotti U, Thiene G (1985) Ultrastructural substrates of dystrophic calcification in porcine bioprosthetic heart valve failure. Am J Pathol 119: 12-21.

Van der Flier A, Sonnenberg A (2001) Function and interactions of integrins. Cell Tissue Res 305: 285-298.

Vongpatanasin W, Hillis LD, Lange RA (1996) Prosthetic heart valves. N Engl J Med 335: 407-416.

Vunjak-Novakovic G, Obradovic B, Martin I, Bursac PM, Langer R, Freed LE (1998) Dynamic cell seeding of polymer scaffolds for cartilage tissue engineering. Biotechnol Prog 14: 193-202.

Walmsley R (1978) Anatomy of the human mitral valve in adult cadaver and comparative anatomy of the valve. $\mathrm{Br}$ Heart J 40: 352-366.

Weber E, Rossi A, Solito R, Sacchi G, Agliano M, Gerli R (2002) Focal adhesion molecules expression and fibrillin deposition by lymphatic and blood vessel endothelial cells in culture. Microvasc Res 64: 47-55.

Weston MW, LaBorde DV, Yoganathan AP (1999) Estimation of the shear stress on the surface of an aortic valve leaflet. Ann Biomed Eng 27: 572-579.

Weston MW, Yoganathan AP (2001) Biosynthetic activity in heart valve leaflets in response to in vitro flow environments. Ann Biomed Eng 29: 752-763.

Wilson GJ, Courtman DW, Klement P, Lee JM, Yeger H (1995) Acellular matrix: a biomaterials approach for 
coronary artery bypass and heart valve replacement. Ann Thorac Surg 60: S353-S358.

Yacoub MH, Kilner PJ, Birks EJ, Misfeld M (1999) The aortic outflow and root: a tale of dynamism and crosstalk. Ann Thorac Surg 68: S37-S43.

Ye Q, Zund G, Benedikt P, Jockenhoevel S, Hoerstrup SP, Sakyama S, Hubbell JA, Turina M (2000a) Fibrin gel as a three dimensional matrix in cardiovascular tissue engineering. Eur J Cardiothorac Surg 17: 587-591.

Ye Q, Zund G, Jockenhoevel S, Hoerstrup SP, Schoeberlein A, Grunenfelder J, Turina M (2000b) Tissue engineering in cardiovascular surgery: new approach to develop completely human autologous tissue. Eur J Cardiothorac Surg 17: 449-454.

Ye Q, Zund G, Jockenhoevel S, Schoeberlein A, Hoerstrup SP, Benedikt P, Turina M (2000c) Scaffold precoating with human autologous extracellular matrix for improved cell attachment in cardiovascular tissue engineering. ASAIO J 46: 730-733.

Yla-Herttuala S, Martin JF (2000) Cardiovascular gene therapy. Lancet 355: 213-222.

Zacks S, Rosenthal A, Granton B, Havenith M, Opas M, Gotlieb AI (1991) Characterisation of cobblestone mitral valve interstitial cells. Arch Pathol Lab Med 115: $774-$ 779.

Zeltinger J, Landeen LK, Alexander HG, Kidd ID, Sibanda B (2001) Development and characterisation of tissue-engineered aortic valves. Tissue Eng 7: 9-22.

Zimmermann WH, Schneiderbanger K, Schubert P, Didie M, Munzel F, Heubach JF, Kostin S, Neuhuber WL, Eschenhagen T (2002) Tissue engineering of a differentiated cardiac muscle construct. Circ Res 90: 223-230.

Zund G, Breuer CK, Shinoka T, Ma PX, Langer R, Mayer JE, Vacanti JP (1997) The in vitro construction of a tissue engineered bioprosthetic heart valve. Eur J Cardiothorac Surg 11: 493-497.

Zund G, Ye Q, Hoerstrup SP, Schoeberlein A, Schmid AC, Grunenfelder J, Vogt P, Turina M (1999) Tissue engineering in cardiovascular surgery: MTT, a rapid and reliable quantitative method to assess the optimal human cell seeding on polymeric meshes. Eur J Cardiothorac Surg 15: 519-524.

\section{Discussion with Reviewers}

P. Taylor: The pressures during valve development are not the same as the maintenance pressures during life. What are the authors views on the flow/pressure conditions required to tissue engineer an aortic valve in a bioreactor? Should increasing pressures be used?

Authors: Fetal blood pressure increases gradually with ongoing maturation, and although there is limited data available, it has been suggested that complete development of all four heart valves takes place under pressure values below $10 \mathrm{mmHg}$, with further remodeling of the structures up to 20 weeks gestation under increasing heart rate (Stock and Vacanti, 2001). A number of previous heart valve bioreactor studies have used pressure ranges increasing above late gestation fetal aortic pressure, with upper values of $55-70 \mathrm{mmHg}$ (Hoerstrup et al., 2000a; Hoerstrup et al., 2002). Although some promising results have been obtained, it would be inter- esting to determine whether or not pressure values closer to those during valve development would improve tissue structure further. Inappropriately high values may inhibit cell proliferation, increase cell-scaffold detachment and may even increase cell death. More gradual increases in pressure over longer time periods, similar to those encountered in utero, may also prove beneficial and may establish a more positive feedback mechanism for tissue development. However, different cell sources and scaffold polymers are likely to be influenced in different manners by varying pressure ranges, even if cultured in identical bioreactor systems; therefore, the problems associated with inadequate valve tissue development can only be corrected with all factors taken together.

S. Jockenhövel: A general point of discussion is the expected market for tissue engineered heart valve prostheses. In my opinion the number of potentially needed implants is significantly over-rated. The high production costs will lead to strict indications e.g. for paediatric heart surgery or for the treatment of acute endocarditis.

Authors: The number of necessary implants may not strictly be over-rated, however, the phenomenal costs that will be involved in quality control processes, and in packaging, sterilization and storage of tissue-engineered heart valves, may certainly limit the scale-up of manufacturing processes early on. The preliminary target market for tissue-engineered heart valves is the paediatric population, where these valves would theoretically grow and remodel with the patient and would eliminate the need for successive reoperations. Once a proof of application and efficacy has been established in this market, manufacturing processes can be scaled up to supply $<60$ years market. As the market size increases, production costs will decrease; this may particularly benefit patients in developing countries where rheumatic fever and rheumatic heart disease continue to have a high prevalence rate.

S. Jockenhövel: The current investigations in that field are encouraging - but we have to take care not to implant a tissue engineered heart valve too early. Animal models like sheep are not ideal models concerning endothelialization and hemostasis and might lead to an early failure of the prostheses in human clinical use like we have seen in tissue engineered small calibre vascular grafts.

Authors: Certainly the SynerGraft ${ }^{\mathrm{TM}}$ valves have shown that animal models have failed to predict the failures in humans (Simon et al., 2003). Animal experimental models can normally be encouraging but it is very difficult to translate the same success rate to humans. With regard to the poor success rates in animal models of heart valve tissue engineering, we strongly feel that it is the fundamental heart valve biological issues that need to be addressed, and significantly more in vitro research must be carried out. Also, the same test models have been used in the heart valve industry for years; more appropriate test models must be developed to be able to further develop living, tissue-engineered alternatives for introduction in the human clinical setting.

\section{Additional Reference}

Stock UA, Vacanti JP (2001) Cardiovascular physiology during fetal development and implications for tissue engineering. Tissue Eng 7: 1-7. 